Lektorált tanulmányok

\title{
A borturizmus múltja, jelene és jövője az Etyek-Budai borvidéken
}

\author{
Szerzők: Mikházi Zsuzsanna ${ }^{1}$ - Sallay Ágnes² - Máté Klaudia ${ }^{3}$ - Csemez Attila
}

A turizmus és a táj kapcsolatának vizsgálata tapasztalataink szerint nem gyakori kutatási téma, pedig a turisztikai kínálat kialakítása során alapvetôen fontos lenne. A táj és a benne élô emberek történelmi, társadalmi, gazdasági változásainak lenyomatai mára turisztikai attrakciókká váltak. Így kialakulásuk, fejlődésük megismerése a turisztikai tervezés-fejlesztés során szükségszerú.

Az Etyek-Budai borvidék története mind turisztikai, mind tájtörténeti szempontból különleges. Egy olyan történeti borvidékrôl van szó, amely már a középkorban is létezett, szerepel a XIX. századi elsô és a filoxéra vészt követô második borvidék-összeírásban is, és amely a XX. század elejére szinte teljesen megszünt, mivel a szólőbirtokok eltûntek. Most mégis virágzik a borturizmus a termôhelyi sajátosságoknak és a kiemelkedő pincészeteknek köszönhetôen. Bár a felmérések szerint kedveltsége és ismertsége még jelentôsen elmarad a "nagyoktól", helyzeti energiái (jó megközelithetôség, a föváros közelsége) és a táji) történeti gyökerekre építő fejlesztések és marketing eredményeként mégis kiemelkedô sikereket ért el az elmúlt 15 évben.

Kulcsszavak: borturizmus, Etyek-Budai borvidék, történeti borvidék, tájérték.

\section{Bevezetés}

A turizmus, a turisztikai célpontok elválaszthatatlanok a táji adottságoktól. Ezek többsége valamilyen formában kötődik a tájhoz, hiszen a látvány, a tájhasználatok összekapcsolódnak azokkal az értékekkel, amelyek miatt a turisták az adott területet felkeresik (1. táblázat). A borturizmus esetében erőforrásként tekinthetünk a kulturális értékekre, a helyi identitástudatra, az elóállított termékekre, az évszázadokon keresztül kialakult infrastruktúrára, a helyi lakosságra és nem utolsó sorban a tájképre (SALLAY et al. 2010).

Etyek Budapest szőlőskertje, a fővároshoz legközelebb fekvô borvidék emblematikus székhelye. Az itt élő emberek már a múltban is szőlőmúvelésből éltek és a jövőjüket is erre szeretnék alapozni. Az elmúlt években a közösség erőfeszítéseinek, illetve a lelkes és tevékeny helyi vállalkozóknak kö-

${ }^{1}$ egyetemi tanársegéd, Szent István Egyetem, mikhazi.zsuzsanna@tajk.szie.hu ${ }^{2}$ habilitált egyetemi docens, Szent István Egyetem, sallay.agnes@tajk.szie.hu ${ }^{3}$ PhD-hallgató, Szent István Egyetem, mate.klaudia@phd.uni-szie.hu

${ }^{4}$ ny. egyetemi tanár, Szent István Egyetem, csemez.attila@tajk.szie.hu szönhetően fejlődésnek indult az idegenforgalom, amelynek alapját természetesen a gasztronómia és az évszázados múltú szőlő- és pezsgókultúra jelenti. A választott mintaterülettel és térségével már több, mint tíz éve foglalkozunk. Számos vizsgálat, kutatás, publikáció és diplomamunka született a Tanszékünk koordinálásával a területre vonatkozóan. A TÉKA (Táj Érték KAtaszter) címú nemzetközi projektünk egyik mintaterülete volt a térség (KOLLÁNYI et al. 2011). A Budavidék Zöldút tervezése kapcsán is több, a jelenlegi kutatásban szereplő településsel foglalkoztunk (BÁRCZINÉ et al. 2011).

Bár a szőlőtermelés és a borászat meghatározó itt, idáig ezzel az aspektussal nem foglalkoztunk. A borvidék tájváltozásait vizsgáltuk elsőként, azt elemezve hogyan alakultak át a szólőterületek (elhelyezkedés, kiterjedés tekintetében) az elmúlt évszázadokban (ld. SALLAY et al. 2017). Most pedig a fennmaradt és újratelepített szőlőre alapozott borturizmusát tekintjük át.

A borturizmus sokrétú fogalom, a pincelátogatástól és borkóstolástól a szüreti eseményekig, borfesztiválokig sok eleme van. Napjainkban a turizmus egyik dinamikusan fejlődó területe a kisebb, speciális turizmus-ágak közül. Ennek okai: a minőségi bor fogyasztásának erősödő tendenciája, a 


\section{Potenciális táji erőforrások a turizmusban}

\begin{tabular}{|c|c|}
\hline Turizmusban való megjelenés & Példa \\
\hline \multicolumn{2}{|c|}{ Eröforrás: Kulturális értékek, autentikus kínálati elemek } \\
\hline Történelmileg kialakult táj, tájhasználat & Szőlők, gyümölcsösök, teraszos müvelés, táblaalakítás \\
\hline Települések & Falvak/majorságok-majorsági épületek, templomok, apátságok \\
\hline Történelmi infrastruktúra & Öntöző rendszerek, védelmi vonalak (árok, fal/domb) \\
\hline Történelmi, közlekedési úthálózat & Szárazföldi és vízi közlekedés, kikötôk-csomópontok \\
\hline Események & Hagyományos ünnepek \\
\hline Minôsités/besorolás/kiemelés & Kulturális örökségi helyszínek \\
\hline \multicolumn{2}{|c|}{ Eröforrás: Helyi identitástudat és hagyományos technikák } \\
\hline Település & Helyi stílus, anyagok használata (kô, fa, agyag: vályog/tégla, nád) \\
\hline Termelés, termékek & $\begin{array}{l}\text { Termelési/mezőgazdálkodási mód, öntözés, vizzgazdálkodás, tápanyag utánpótlás/ } \\
\text { trágyázás, eszközök, erózió és megelőzése }\end{array}$ \\
\hline Közösség/társadalom & $\begin{array}{l}\text { A települési történelemre vonatkozó helyi/közösségi tudás és emlékezés, } \\
\text { társadalmi hálózatok }\end{array}$ \\
\hline Élelmiszer előállitás és tartósítás & Hagyományos receptek és módszerek \\
\hline \multicolumn{2}{|r|}{ Erőforrás: Termékek } \\
\hline $\begin{array}{l}\text { Mezőgazdasági termékek: } \\
\text { Élelmiszer (a helyi klimához és a } \\
\text { termöföldi adottságokhoz igazodva) }\end{array}$ & Gabonafélék, gesztenye, bor, olaj, fúszerek, zöldségek, gyümölcsök \\
\hline Takarmány & Széna, takarmánynövények (rét, legelő gazdálkodás) \\
\hline Anyagok & Erdő: bútorkészités, fütóanyag, kosárfonás, munkaeszközök készitése \\
\hline Egyéb & Virágok \\
\hline $\begin{array}{l}\text { A lejtôs területek, rézsük termékei: } \\
\text { Élelmiszer }\end{array}$ & Gyümölcs, szólő \\
\hline Takarmány & Széna (rét, legelő gazdálkodás) \\
\hline Orvoslás & Gyógynövények \\
\hline \multicolumn{2}{|r|}{ Eröforrás: Infrastruktúra } \\
\hline Eszközök & Helyi utak, vasutak, kisvasutak \\
\hline Rekreációs infrastruktúra & A térségen átvezetô utak, kilátópontok \\
\hline $\begin{array}{l}\text { Az ellátás infrastruktúrája: szállás és } \\
\text { étkezés }\end{array}$ & $\begin{array}{l}\text { Étterem/borkóstoló helyek (boros pincék)/ helyi termékeket ajánló üzletek } \\
\text { Szállás (farmok/tanyák, falusi vendégfogadás) }\end{array}$ \\
\hline \multicolumn{2}{|c|}{ Erőforrás: Helyi lakosok } \\
\hline Ellátók, kiszolgálók & $\begin{array}{l}\text { Helyi termékek árusítása } \\
\text { Idegenforgalmi szolgáltatások } \\
\text { Utazásszervezôk } \\
\text { Helyi utas szállitási szolgáltatások } \\
\text { Idegenvezetoók }\end{array}$ \\
\hline \multicolumn{2}{|r|}{ Eröforrás: A táj(kép) szépsége } \\
\hline Történelmi értékek, történelmi gazdagság & Köfalak, épületek, falvak, öreg sövények, mezsgyék \\
\hline $\begin{array}{l}\text { Egy táj összefüggó, harmonikus } \\
\text { benyomása és befogadhatósága }\end{array}$ & $\begin{array}{l}\text { Hagyományos táj, amit élelmiszer termelésre használtak. Egyértelmú } \\
\text { területhatárok, amelyek irányítják a tekintetet, emelik a térhatást. }\end{array}$ \\
\hline Szegélyek és tagoltság & $\begin{array}{l}\text { A szegélyek mennyisége határozza meg a tagoltságot. Az eltérô méretü, váltakozó } \\
\text { területek mozgásra késztetik a szemet. }\end{array}$ \\
\hline Nyíltság & Belátható, erdô vagy más látványkorlát nélküli területek. \\
\hline Egyediség & Az elemek össze nem téveszthetô sajátos megjelenése, együttese. \\
\hline Változatosság & $\begin{array}{l}\text { Vizuális változatosság, amely a geomorfológián és a biodiverzitáson keresztül } \\
\text { érvényesül. }\end{array}$ \\
\hline
\end{tabular}


Lektorált tanulmányok

hazai bortermelés családi pincészetekhez való kötődése, a minőségi bortermelés előtérbe kerülése, a borok, borokkal kapcsolatos kérdések ismeretének társasági divatja. A termőhelyen, vagy akár egy borfesztiválon történő borkóstolás számos más turisztikai tevékenységgel könnyen összeköthető: lehet kirándulni, a vidéket, a vidéki embereket, a tradicionális falusi életet megismerni, hagyományos gasztronómiai élményeket szerezni, kóstolás elótt egy érdekes kisvárosban sétálni, kóstolás után egy fürdôt meglátogatni (VÁRHELYI 2012, MICHALKÓ et al. 2011).

Az egyes borfajták különbözó helyeken és különböző természeti adottságok mellett termelődnek. A borok sokfélsége és adott tájegységekhez való köthetôsége elősegíti a borturizmust. A termőhelyek sajátosságai nagy jelentőséggel bírnak, és a bor termőhelye a bort szeretó turisták számára turisztikai vonzerônek számít. Különösen igaz ez, ha a termóhely:

- híres, jó boroknak a termelési helye,

- szép természeti környezetben található,

- hagyományosan érintetlen, vagy a turizmus igényei szerint fejlesztett infrastruktúra található ott (például látványpince, borvendégló),

- ismert borász várja a vendégeket,

- érdekes eseményeket szerveznek (ezek közül értelemszerúen az egyik legérdekesebb maga a szüret és a szürethez kapcsolódó programok) (VÁRHELYI 2012).

Hazánkban a borvidékek többsége kicsi, a potenciális látogatók számára könnyen beazonosítható: gyakorlatilag mindenki tudja, hol van például Villány, Eger vagy Tokaj. Jól körülhatárolhatók, így viszonylag könnyen szervezhetők borutak is. Ha a termőhely közelében további számottevő turisztikai vonzerôt is találunk, akkor természetesen nagyobb eséllyel választják az odautazást a potenciális vendégek. Ezért a táj, a tájértékek, a településtörténet feltérképezése a borturizmus kiépítésekor is fontos.

Ha az út elsődleges motivációja a borral kapcsolatos, akkor borturizmusról beszélhetünk. De jellemző az is, hogy az elsődleges motiváció más turizmusfajta, amelyet jól kiegészít a borturisztikai kínálat. A borturizmusnak jelentôs a szerepe a hagyományok, sőt a hagyományos szőlőfajták megőrzésében. A magyarországi bor- és gasztronómiai turizmus szempontjából fontos kérdés, hogy az utazók megfelelő tájékoztatást kapjanak az adott régióra, tájegységre, településre jellemző étel- és borspecialitásokról (MT RT. - M.Á.S.T. 2006, MT ZRT. 2013). Hazánkban még nem jellemző, hogy a fogyasztók tisztában lennének a bortermő helyek sajátosságaival, jel- lemző és honos szőlő- és borfajtáival. De ez változóban van, s ebben a borturizmusnak nagy szerepe van.

A következô évtizedekben, elsősorban a klímaváltozás hatására minden borvidék, így a hazaiak is jelentős kihívásokkal fognak szembenézni. A változások elkerülhetetlenek, de a megfeleló stratégiával, a táji adottságok figyelembevételével elókészített fejlesztések hosszútávon a hazai borturizmus fennmaradását, fejlődését eredményezhetik.

Célkitúzéseink között szerepel a táj, a tájelemek, a tájértékek és a turizmus kapcsolatának vizsgálata az Etyek-Budai borvidék borturizmusának tükrében. Ehhez részletes tájtörténeti kutatást végeztünk (fóként területhasználati statisztikai adatok elemzésével) a szőlőterületek változását vizsgálva. Felmértük a tájértékeket, és kiemeltük a szólészettel-borászattal kapcsolatosakat, amelyek a borturizmus vonzeróiként jelennek/jelenhetnek meg. Áttekintettük a borvidék turisztikai kínálatát, specialitásait, majd lehetséges kapcsolatokat kerestünk a táji értékek és a borturizmus között. Célunk táji szemléletú át- és kitekintést nyújtani, ami elősegítheti a borvidék borturizmusának fejlesztését.

\section{Elméleti háttér}

\subsection{AZ ETYEK-BUDAI BORVIDÉK ELHELYEZKEDÉSE, FÖBB JELLEMZÖI}

A borvidék a Gerecse-hegység déli részétôl a Velencei- és a Budai-hegységig húzódik ${ }^{5}$. A valóságban semmi köze a hajdani Budai Borvidékhez. Az Etyek-Budai borvidék teljes szőlőkataszteri területe 5632 ha, melyból 3927 ha I. osztályú. A szőlőültetvények területe az egész termőhelynek csak mintegy 30\%-a, 1694,8 ha ${ }^{6}$. A borvidék települései három körzetre oszlanak: az Etyeki körzet, a Budai körzet és a Velencei körzet. A termékleírás alapján a borvidék települései (1. ábra):

- Pest megye: Biatorbágy, Budafok, Budajenó, Budakeszi, Budapest XII. kerület 9597/1 hrsz., Budapest XXII. kerület, Páty, Pilisborosjenő, Telki, Tök, Üröm, valamint

- Fejér megye: Alcsútdoboz, Bicske, Csabdi, Etyek, Felcsút, Gárdony, Gyúró, Kajászó, Kápolnásnyék, Martonvásár, Nadap, Pákozd, Pázmánd, Sukoró, Tordas, Vál, Velence.

${ }^{5} \mathrm{http}: / /$ www.etyekbudaiborvidek.hu/borvidek-bemutatasa.mw ${ }^{6} \mathrm{https} / / /$ borterasz.hu/etyek_budai_borvidek 
Az Etyek-Budai borvidék települései a 2017. évi termékleírás alapján

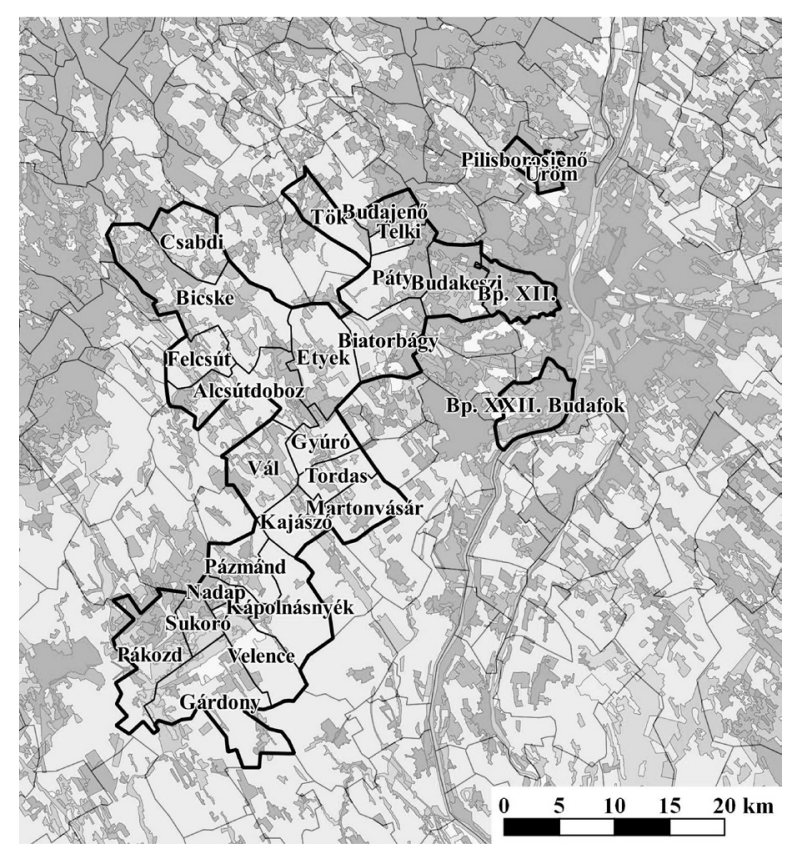

Forrás: A 607/2009/EK, Az ETYEK-BUDA oltalom alatt álló eredetmegjelölés termékleírása alapján ${ }^{7}$

Az Etyek-Budai borvidék mai formájában az újabb borvidékek közé tartozik. Az Etyeki borvidék ezen a néven először 1990-ben jött létre a Velencei borvidék megújított ültetvényeiből és az egykori etyeki pezsgőalapbort termeló Törley szólóbirtokon létesült Henkell-Söhnlein-gazdaság szőlooültetvényeiből. Ehhez csatolták az 1997. évi bortörvényben a Budai-hegység környéki szőlőtermelő községeket ${ }^{8}$.

A Dunántúli-középhegység északkeleti részén húzódó borvidék klímája húvösebb az országos átlagnál, az évi középhômérséklet $9,5-10,5^{\circ} \mathrm{C}$, az évi átlagos csapadékmennyiség pedig $650 \mathrm{~mm}$, aminek legnagyobb része a vegetációs idószakban hullik le. A borvidék klímájának fontos jellemzője, hogy a borvidék egész területén folyamatos széljárás jellemző, az uralkodó szélirány az észak-nyugati szél, mely mindig húvös légtömegeket szállít a területre. A filoxéra vészt követóen a helyi borászok olyan nyugati fajtákat vontak be a termesztésbe, amelyek jól alkalmazkodtak a helyi ökológiai adottságokhoz (például a XIX. század végén, a XX. század elején az olaszrizlinget, szürkebarátot, illetve a borvidéken meghatározó chardonnay fajtát), és a belólük készült borokban felfedezhették Etyek-Buda termőterületének egyedi jellemzőit. Az Etyek-Budai borok közös jellemzője, hogy a bo-

\footnotetext{
${ }^{7}$ http://boraszat.kormany.hu/download/e/ea/12000/Etyek-Buda\%20OEM_v4.pdf ${ }^{8}$ https://borterasz.hu/etyek_budai_borvidek
}

rok meglehetôsen illat- és zamatgazdagok. Magas savtartalmuk ellenére savaik érettek, üdék, amely garantálja az Etyek-Budai borok frissességét (HNT 2017).

\subsection{TÁJALAKULÁS TÖRTÉNET AZ ETYEK-BUDAI BORVIDÉKEN}

A mai Etyek-Budai borvidéken több évszázados hagyománya van a szőlőtermesztésnek és a borokhoz kapcsolódó vendéglátásnak. Óbuda térségében a szólótermesztés a rómaiak óta (Aquincum) dokumentáltan ismeretes. A középkori Buda vörösbora messze földön ismert volt. Evlia Celebi török világutazó az 1660-as években járt Budán és útleírásában Buda, és Óbuda környékén „7000 szóllőkertről" írt és arról, hogy a város vendéglőiben vörös és fehér borokat egyaránt felszolgálnak (KARÁCSON 1904). Budán a török megszállást követô visszafoglalása, 1686, után mindenki ott foglalt magának területet, azaz szólót, szántót, rétet, ahol akart (KARÁCSON 1904). A birtokok nagyok voltak, 1713-ban a városi tanács jelentése szerint 2252 szőlóbirtok volt, aminek terjedelme 4561 negyed, azaz 2318 katasztrális hold volt (KARÁCSON 1904). A szőlőmúvelés jelentős gazdasági tevékenység volt, nem véletlen, hogy a jó kitettségú domboldalakat, hegyeket szőlő borította. A budai szőlők nagy termelési értéket képviseltek, a bort a városban értékesítették, de jutott exportra is.

Fényes Elek 1851-ben készítette el Magyarország geográfia szótárát, melyben az összes hazai települést áttekintette és röviden jellemezte (FÉNYES 1851). Ebben az összeírásban a mai Etyek-Budai borvidék települései egy kivétellel (Kajászó) megjelennek. Szinte az összes település esetében találunk utalást a leírásban a szólótermesztésre, vagy az itt elóállított borokra. A leírás alapján kiemelkedő mértékú (mennyiségi és/vagy minőségi értelemben) szőlőtermesztés Alcsúton, Etyeken, Tordason, Válon, Budafokon, Budakeszin, Borosjenőn és Velencén volt. A mai borvidék települései közül Bicskén és Gárdonyban nem volt hagyománya a szőlőtermesztésnek, bortermelésnek. A legjelentősebb borászati központnak ebben az időszakban egyértelmúen Budafok (Promontorium) és Alcsút számított. Érdekesség, hogy Borosjenó (Weindorf) már a nevében is a borászati hagyományokat hordozta. A termelt bor fő felvevő piaca ebben az időszakban egyértelmúen Buda városa volt.

A filoxéra vész, a kiterjedt védekezés ellenére, az akkori Budai borvidéken is nagy pusztítást végzett. A kipusztult szőlőültetvények sorsa elsősorban az elhelyezkedésük függvényében változott: a Budapest belterületi részein található területek mondhatni kapóra jöttek az egyesítés utáni buda- 
Lektorált tanulmányok

Az Etyek-Budai szőlooterületek változása a különböző történelmi korszakokban

\begin{tabular}{|c|c|}
\hline A filoxéra vészig tartó idôszak (-1895) & $\begin{array}{l}\text { A középkorban kialakult, hagyományos szölôterületek tovább } \\
\text { élése. }\end{array}$ \\
\hline $\begin{array}{l}\text { A filoxéra vész után, az elsó világháború végéig tartó idôszak } \\
\text { (1895-1914) }\end{array}$ & $\begin{array}{l}\text { Területi visszaesés, sok helyen megszûntek a szölöterületek. } \\
\text { Termesztett fajták megváltozása. }\end{array}$ \\
\hline A két világháború közötti időszak (1918-1939) & Lassú növekedés, de nem éri el a filoxéra elötti szintet. \\
\hline A szocialista tervgazdaság idôszaka (1945-1989) & $\begin{array}{l}\text { A szólötermesztô területeken inkább tömegtermelés a } \\
\text { minôségi fajták helyett. }\end{array}$ \\
\hline $\begin{array}{l}\text { A rendszerváltozás utáni időszak, melyben az európai uniós } \\
\text { csatlakozás utáni időszak is markánsan elkülönithető (1990- } \\
\text { tôl, illetve 2004-től napjainkig) }\end{array}$ & $\begin{array}{l}\text { Területi és minóségi változások. Jó minóségú fajták } \\
\text { visszatelepitése, minōségi borok elóállitása. Hagyományok } \\
\text { újraélesztése, a bor és a szôlőtermesztés turisztikai } \\
\text { jelentôségének növekedése. }\end{array}$ \\
\hline
\end{tabular}

Forrás: saját szerkesztés

pesti fejlesztéseknek, ezeken a területeken alapvetóen a beépítés, a lakóterületi hasznosítás vált jellemzővé. Így jöttek létre például a Gellérthegy oldalában a villanegyedek a századfordulón. Azokon a területeken, ahol a lakosságban volt igény a termesztés fenntartására, vagy fajtaváltással ismét szőlőt telepítettek, vagy a kiváló adottságú területeket más gyümölcs (elsősorban csonthéjasok) termesztésére hasznosították. Erre példa a Budaörs területén kialakított nagykiterjedésú őszibarack ültetvények. A filoxéra után jelentek meg a szôlőtermesztésre korábban kevésbé hasznosított területeken a szőlöültetvények az Etyeki térségben, ahol azóta töretlen fejlódést figyelhetünk meg (SALLAY et al. 2012, 2017). Az etyeki térségben a filoxéra után visszatelepített szólóterületek a rendszerváltozásig többé-kevésbé állandóak maradtak, 1989 után viszont egyes településeken, ilyen például Etyek, komoly területnövekedés figyelhetó meg, melyet az Európai Unióhoz való csatlakozás tovább erósített.

Termesztés szempontjából több korszak is lehatárolható, melyek az ország szinte minden hagyományos szőlótermesztési területén elkülöníthetók. Ezeket a korszakokat ismerteti a 2. táblázat.

\subsection{TERÜLETHASZNÁLATI STATISZTIKA AZ ETYEK-BUDAI BORVIDÉKEN}

A hivatalosan 1997-ben megalakult Etyek-Budai borvidék változásait kizárólag a mai területi lehatárolás alapján lehetséges elvégezni. A borvidék településeinek kiterjedése és közigazgatási egysége (Budapest XXII. kerületének kivételével) az évszázadok során alapvetően nem változott, csak a beépített területek mérete nótt, ezért viszonylag állandónak mondható. A szólóterületek változása a területhasználatra vonatkozó adatokon kívül a történeti térképek elemzésével is jól nyomon követ- hetô. Az Etyek-Budai borvidék szőlóterület-kiterjedésének vizsgálatához egy korábbi kutatásunkban a Keleti Károly által írt, 1873-as adatokat tükröző szőlészeti statisztikát, a Központi Statisztikai Hivatal 1895 és 1984 közötti idôszakra vonatkozó településsoros területi adatait, valamint a European Environment Agency 2000-től 2012-ig tartó Corine Land Cover adatbázisának területi adatait használtuk fel (KELETI 1875, KSH 1988, EEA 2012).

Az 1895-től 2012-ig tartó statisztikai felmérések adataiból egyértelmúen kirajzolódik az Etyek-Budai borvidék településeinek területhasználat-változása. A 2. ábrán az Etyek-Budai borvidék szôlöterületeinek változásai láthatók. Keleti Károly 1875-ben kiadott szőlőstatisztikája még a filoxéra előtti állapotról számol be. Ebben az évben a borvidék településein összesen 4779 hektáron folyt a szőlőmúvelés. A következő adat az 1895ös állapotot mutatja, ekkor a filoxéra már jelentós pusztítást végzett az országban, az Etyek-Budai borvidék településeinek szőlőterülete az ötödére csökkent, mindösszesen 821 hektár szőlő maradt. $\mathrm{Az}$ akkori kormány sikeres szőloúúratelepítési kezdeményezéseinek köszönhetően 1913-ra a szôlóterületek kiterjedése már meghaladta a 2000 hektárt és az elkövetkező hét évtizedben ez az arány jelentôsen nem változott. A rendszerváltozás után újra növekedésnek indult a szőlőterületek kiterjedése, 2000-ben több mint 3900 hektár állt szólőmúvelés alatt (melynek oka a szovjet piacra termeló nagyüzemi szőlőtermesztés), ám a filoxéra előtti kiterjedést nem közelítette meg és azóta sem érte el. 2000-től kezdődően - feltehetően az Európai Unió agrárpolitikai intézkedéseinek következtében - jelentős csökkenés indult el, a legfrissebb felszínborítási adatok szerint (EEA 2012) a településeken összesen 2704 hektár áll szőlómúvelés alatt, mely alig több mint a filoxéra előtti kiterjedés fele. 
Az Etyek-Budai borvidék településeinek szőlóterülete (1873-2012)

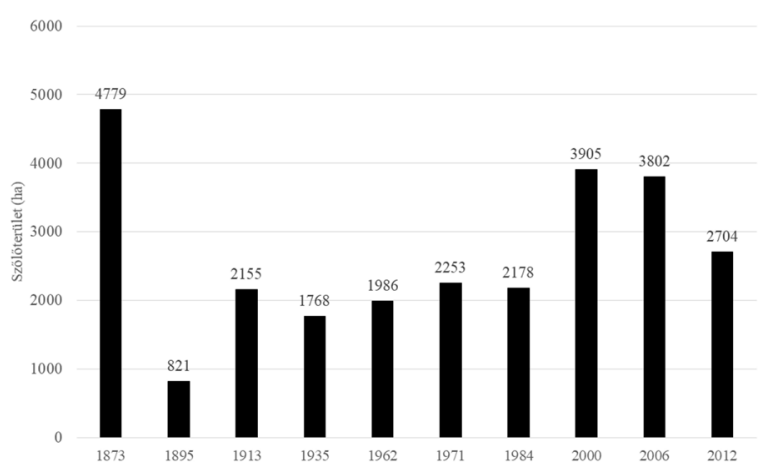

Forrás: Keleti 1875, KSH 1988, EEA 2012

A 2. ábrán szerepló adatokat a fent említett három statisztikai összeírás településenkénti összegzése alapján számítottuk ki. A Hegyközségek Nemzeti Tanácsa 2011 és 2016 közötti termőterületre vonatkozó statisztikája eltérő értékeket mutat (3. táblázat). Az eltérés nagy valószínúséggel abból ered, hogy míg a statisztikai adatok a borvidék településeinek területére eső összes szőlőterületet számításba vették, addig a Hegyközségek Nemzeti Tanácsa csak a borvidék szóló termóhelyi katasztere szerinti I. és II. osztályú határrészein fellelhető termőterületeket összesítette.

3. táblázat

Szôlő termôterület nagysága (ha) az Etyek-Budai borvidéken

2011 és 2016 között a Hegyközségek Nemzeti Tanácsa szerint

\begin{tabular}{|c|c|c|c|c|c|c|}
\hline $\begin{array}{c}\text { HNT adatai } \\
\text { (ha) }\end{array}$ & 2011 & 2012 & 2013 & 2014 & 2015 & 2016 \\
\hline $\begin{array}{c}\text { Etyek-Budai } \\
\text { Borvidék }\end{array}$ & 1440,76 & 1314,11 & 1394,03 & 1363,67 & 1398,58 & 1403,37 \\
\hline
\end{tabular}

Forrás: HNT (2017)

\subsection{TÁJI/TÁJKÉPI SAJÁTOSSÁGOK AZ ETYEK-BUDAI BORVIDÉKEN}

Az egyes borvidékeink karakteresen eltérnek egymástól mind a termesztett szőlók, mind a borok, mind a szőlőtermesztés táji megjelenésében. A tájkarakter jellegzetes elemei ebben az esetben a szőlőmúvelés elemei: a szőlósorok, a támfalak, a teraszok, a pincék és a pincesorok. A történelmi borvidékeink hegyvidéki területeken találhatóak, ezért ezek esetében a tájképben legkarakteresebben a szólómúveléshez kapcsolódó teraszrendszer jelenik meg, melyhez a termesztett szólófajtájától függő metszési, kordonázási mód társul (például Badacsonyi, Szekszárdi, Tolnai borvidék).

A később kialakult, jellemzóen sík vagy dombvidéki borvidékek esetében a tájképben a szólósorok, a termesztéshez kapcsolódó építmények váltak a tájkarakter elemévé. A síkvidéki szőlőbirtokok esetében az elmúlt évtizedekben a nagyüzemi szőlótermesztés vált jellemzővé (ebben az időszakban a borászatok a gyengébb minőségú, úgynevezett tömegborok elóállítására rendezkedtek be), melynek tájképi megjelenése eltér a hagyományostól (például a Móri borvidék). Vannak olyan borvidékeink is, ahol vegyes termesztés látható, például: a Kiskunsági borvidéken a gyümölcsfákkal vegyes ültetés, vagy a Balatonboglári (más néven Dél-balatoni) borvidék, ahol erózióvédelemre pillangósokat ültetnek a szólósorok közé. A turizmus szempontjából mind a termelt bor, mind a karakteres tájkép vonzerő lehet, melyhez egyéb fejlesztésekkel (például szálláshely, programok, borút, további vonzerôk) lehet kapcsolódni.

A tájértékek fogalmát az 1970-es években Mócsényi Mihály vezette be elôször a szakmai köztudatba (CSEMEZ - MŐCSÉNYI 1983). Az első értelmezések alapján még csak a mezőgazdasági területeken található, emberi hatásra kialakult értékeket nevezték egyedi tájértékeknek, mostanra a fogalom jelentése kibővült: egyrészt nemcsak a települések külterületein található értékeket nevezzük tájértékeknek, hanem a belterületeken lévőket is, másrészt manapság már a szabvány természeti értékeket is egyedi tájértéknek lehet nevezni. A hatályos szabvány alapján egyedi tájértéknek az adott tájra jellemző olyan természeti értékeket, képződményeket és emberi tevékenységgel létrehozott tájalkotó elemeket tekintjük, amelynek természeti, kultúrtörténeti, tudományos, vagy esztétikai szempontból a társadalom számára jelentósége van (MSZ 20381:2009).

A Budapesti Corvinus Egyetem Tájépítészeti Kara a Vidékfejlesztési Minisztérium Környezet- és Természetvédelmi Helyettes Államtitkárságával, a KÖH-hel (Kulturális Örökségvédelmi Hivatal), a KÖSz-szel (Kulturális Örökségvédelmi Szakszolgálat) és a FÖMI-vel (Földmérési és Távérzékelési Intézet, 2017. január 1-tól Budapest Fôváros Kormányhivatala Földmérési, Távérzékelési és Földhivatali Fóosztály, röviden BFKH FTFF) közösen 2009 őszén kezdte meg az úgynevezett TÉKA projekt keretében a magyarországi tájértékek összegyújtését, melynek eredményeképpen 2011 tavaszától egy átfogó információs rendszerbe foglalva az interneten találhatóak meg az addig felmérésre került tájértékek (www.tajertektar.hu).

A Felmérési Munkacsoport a projekt kezdetekor összeállított egy listát azokról a tájelemekról, 
Lektorált tanulmányok

melyek tájértékként szóba kerülhetnek. A tájértékeket a szabvány alapján három főtípusba sorolták be, melyek a következők: kultúrtörténeti, természeti és tájképi. A felmérés során munkatársaink a szakmában szokásos metodikát követték:

- elózetes információgyújtés (térképi és írott források feldolgozása, korábbi rendezési tervek áttekintése, adatbázisok, régi felmérések);

- helyszíni bejárás (adatlap, GPS koordináták, fényképek);

- felmért adatok rögzítése a BCE tájértéktárában (www.tajertektar.hu);

- szükség esetén utólagos kiegészítő adatok gyújtése;

- adatok validálása (minőségbiztosítás);

- adatok összerendezése;

- adatok áttöltése a TÉKA adattárába.

A Tájértékek kataszterezéséról szóló MSZ 20381:2009 szabványt a felmérés során kiegészítették az úgynevezett változatokkal, amelyek közé több, a szőlótermesztéssel kapcsolatos érték került be. Alapvetően megállapíthatjuk, hogy a szőlőtermesztéssel, borászattal kapcsolatos egyedi tájértékek a kultúrtörténeti, azon belül a termeléssel kapcsolatos egyedi tájértékek közé tartoznak (4. táblázat).

4. táblázat

Borászattal, szólótermesztéssel kapcsolatos tájértékek a TÉKA felmérésben

\begin{tabular}{|l|l|}
\hline \multicolumn{2}{|c|}{ Típus: Termeléssel kapcsolatos egyedi tájértékek } \\
\hline \multicolumn{2}{|c|}{ Altípus: Agrártörténeti egyedi tájérték } \\
\hline Majorság & \multicolumn{1}{c|}{ Változat } \\
\hline \multirow{2}{*}{ Pince } & szórvány pincék \\
\cline { 2 - 2 } & pincesor \\
& pincetelep \\
\cline { 2 - 2 } & pincefalu \\
\hline Présház & \\
\hline \multirow{2}{*}{ Múvelési ág szerkezet } & $\begin{array}{l}\text { hagyományos múvelési } \\
\text { mód, múvelési irány }\end{array}$ \\
\cline { 2 - 2 } & tagoltság, elválasztottság \\
\hline Borház & \\
\hline Egyedi tájhasználat & teraszírozás \\
\cline { 2 - 2 } & nadrágszíj parcellák \\
\hline Tájfajta & \\
\hline
\end{tabular}

Forrás: TÉKA projekt, MSz 20381:2009 kiegészítése

Az Etyeki körzet településein 508 tájérték került összeírásra, melybőll 177 (35\%) kapcsolódik a szőlészethez és borászathoz (pincék, présházak, szőlő- ültetvény - hagyományos tájgazdálkodás, szőlöültetvény - tájfajta, felhagyott gyümölcsös). A három borvidéki egység közül itt található a legtöbb, a teljes borvidék ilyen jellegú tájértékeinek 53\%-a. A Budai körzet településein 697 tájérték került összeírásra, melyből 144 (21\%) kapcsolódik a szólészethez és borászathoz (présházak, pincék, pincetelep, szólóülttetvény - hagyományos táigazdálkodás, szólóhegy). A három borvidéki egység közül itt található a második legtöbb tájérték. A Velencei körzet településein 293 tájérték került összeírásra, melyből 14 (5\%) kapcsolódik a szólészethez és borászathoz (csak pincék). A három borvidéki egység közül itt található a legkevesebb tájérték. Az Etyek-Budai borvidék jellegzetes tájelemei a körpincék, a fennmaradt sváb házak, régi borászati eszközökkel gazdagítva.

\subsection{A BORTURIZMUS SAJÁTOSSÁGAI MAGYARORSZÁGON ÉS AZ ETYEK-BUDAI BORVIDÉKEN}

Magyarország jelentős hagyományokkal büszkélkedhet a borkultúra terén, ennek ellenére gyakorlatilag alig ismert a világ borpiacán. A magyar lakosság borászat iránti érdeklódése egyre növekvő, ugyanakkor a borfogyasztás csökkenő tendenciát mutat. Több felmérés is vizsgálta a magyar lakosság utazási, alkoholfogyasztási/borfogyasztási és gasztronómiai szokásait az elmúlt időszakban (MT RT. - M.Á.S.T. 2006, BORMARKETING MÚHELY NONPROFIT KFT. 2013a, NAGY BOR TESZT 2016). Bár a minták nagysága és összetétele eltérő volt, elmondható, hogy a válaszadók majdnem $70 \%$-a fogyaszt bort valamilyen gyakorisággal. A borfogyasztók többsége az otthonuk után vendéglátó egységekben vagy borral kapcsolatos rendezvényeken fogyaszt legtöbbször (3. ábra).

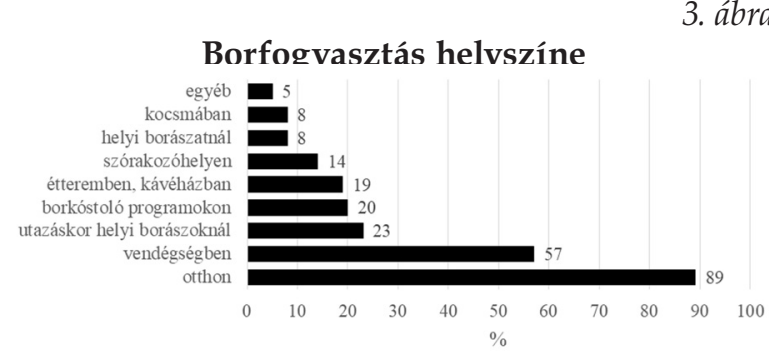

Forrás: BORMARKETING MŰHELY NONPROFIT KFT. (2013a), p.16. Megjegyzés: $\mathrm{N}=1550$, teljes minta, akik bort fogyasztanak, több válasz lehetséges

$\mathrm{Az}$ adatok egyértelmúen azt mutatják, hogy a gasztronómiai rendezvények, borfesztiválok, borkóstolások az utazások során a programok fontos 
részét képezik. A bort rendszeresen vásárlók számára fontos szempont (az ár és a magyarországi származás mellett) a borvidék és a szólőfajta, az évjárat és a termelő pincészet. Magyarország 22 borvidéke a borkedvelő fogyasztók között közismertnek mondható, de csak egy részük számít sikeres borturisztikai desztinációnak. A hazai borvidékek ismertsége meglehetôsen jó a magyar lakosság körében. A MT RT. - M.Á.S.T. (2006) kutatásában a megkérdezettek jellemzően 4-5, átlagosan 4,7 borvidéket tudtak felsorolni. A legismertebb a Tokaj-hegyaljai (79,5\%), az Egri (72,1\%) és a Badacsonyi $(60,0 \%)$ borvidék (MT RT. - M.Á.S.T. 2006). A BORMARKETING MUUHELY NONPROFIT KFT. (2013b) vizsgálta a hazai borvidékek kedveltségét, azaz a borvidékek borainak népszerúségét. Az adatok alapján három kimagaslóan népszerú borvidéket találtak: Tokaj, ezt szorosan követi Eger és Villány. Ezeket a borvidékeket a borfogyasztók fele kedveli. Népszerúségben a következő csoport Badacsony, Balaton-felvidék és Szekszárd, ezek kedveltsége már jóval elmarad a három vezető borvidékétôl, a fogyasztók alig ötöde kedveli őket a legjobban. Népszerúségben a következő Sopron, Balatonboglár, Pécs és a Balatonfüred-Csopak borvidék csoport, amit a borivók tizede kedvel. A további 12 borvidék (közöttük az Etyek-Budai borvidék is) valójában csak nagyon kis preferenciával rendelkezik, feltehetően a környék lakói kedvelik (4. ábra).

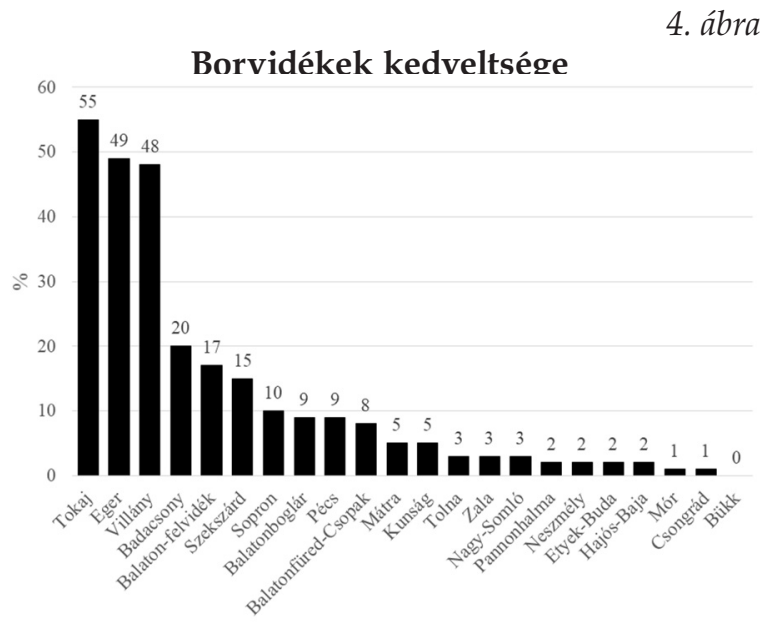

Forrás: BORMARKETING MÜHELY NONPROFIT KFT. (2013a), p. 37 Megjegyzés: $\mathrm{N}=1550$, teljes minta, akik bort fogyasztanak, több válasz lehetséges

A NAGY BOR TESZT felmérésében - amelyik a legfrissebb - a borvidékek kedveltsége a korábbi kutatási eredményekhez hasonló mintázatot mutatott. A három nagy kimagasló eredményt ért el, Villány, Eger, Tokaj sorrendben. Őket a három követô kíséri: Szekszárd, Badacsony, Balaton-felvidék. De ezek népszerúsége jóval elmarad a három vezető borvidékétől. Valamint 10\% fölött nyilatkozták még, hogy az alábbi borvidékekről rendszeresen fogyasztanak bort: Sopron, Balatonfüred-Csopak, Mátra, Etyek-Buda, illetve Dél-Balaton.

A magyarországi borturizmus fejlődését nagyban elősegítette, hogy az 1990-es évek elejétől egyre több borász jelent meg a közvélemény előtt, a fogyasztók a bort össze tudják kötni a termelővel. A fogyasztók körében egyre népszerúbbé váltak a borászatok, nőtt a pincelátogatások iránti érdeklődés. Egy-egy pincelátogatás alkalmával a vendégek megismerkedhetnek a borászattal, a borkészítéssel és a különböző borokkal, ami a továbbiakban a borfogyasztás kedveltségét is növeli. Az ebben rejlő lehetőségeket maguk a borászok is felismerték, egyre gyakoribbak a pincészetek fejlesztései, a szolgáltatások bővítése, a vendégek számára komplex szolgáltatás nyújtása. A hazai borturizmust támogatja, hogy a bortermelók saját maguk is értékesíthetik boraikat az előállítás/bortermelés helyszínén (MT ZRT. 2006).

\section{Borturizmus és borturizmushoz köthetố vonzerók az Etyek-Budai borvidéken}

\subsection{A KLASSZIKUS BORTURIZMUS ELEMEI}

A borvidék legtöbb borászata Etyeken található és a legtöbben a bort is Etyek nevéhez kötik. Az Etyeki Borút Egyesület munkájának köszönhetôen 3 túra került kialakításra: „A gasztronómia útján” (Etyek), „Etyeki túra (múlt és jelen)” (Etyek), "Ízelítő a borvidékből” (Tök, Zsámbék, Felcsút, Alcsútdoboz, Etyek, Páty). A rendezvények kapcsolódnak a borutakhoz, így ezek alkalmával a látogatottságuk magas, valamint az „Etyeki Szüreti Barangoló" kifejezetten a borutakhoz kapcsolt, évente megrendezésre kerülő program. A Velencei-tó környéke leginkább nyári fürdőhelyként látogatott jelentős turisztikai célpont, a borvidék részeként nagyon kevesen ismerik. A Velencei-tó környéki települések borászainak összefogására 2001-ben jött létre a Velencei-tó környéki Borút Egyesület.

A fejlett turizmushoz elengedhetetlenek a komplex szolgáltatások. Ezen a téren az Etyek-Budai borvidék nagyon erôs. Számos jól felszerelt, kiváló minőségú szolgáltatást nyújtó szállás- és vendéglátóhely található itt. Ezek kihasználtságát a borászathoz és szőlőmúveléshez kapcsoló- 
Lektorált tanulmányok

dó sokszínú programkínálat biztosítja. Az egész borvidék népszerú fesztiváljairól és rendezvényeiről híres (például: Etyek Pincefesztivál évente május végén vagy Budafoki Pezsgő és Borfesztivál szeptemberben). Éves rendezvénynaptáruk nincs, de a kiemelkedó események dátumai már év elején megjelennek a honlapon. A bortermelés legfontosabb, leglátványosabb eseménye a szüret és a szüreti fesztivál, ami a borral kapcsolatos eseményturizmus egyik legfontosabb fajtája Etyeken is. De fontosak a gasztronómiát és a borkóstolást ötvöző programok is, mint például a térségnek nevet szerzô, szeptember végén megrendezésre kerüló Etyeki Kezes-lábos gasztronómiai Fesztivál (ma már Etyeki Piknik). Számos más, a borhoz és a szólótermeléshez kapcsolódó, programjai is vannak a borvidéknek: "Etyeki Légyott” (Öreghegy), „Etyeki Piknik” (Újhegy), „Etyeki Szüreti Barangoló" (Etyeki Borút).

A vidékiség és a nagyváros közelsége egyszerre hozta talán azt a lehetóséget a borvidéknek, hogy településein és közvetlen környezetében szép számmal találhatók helyi termék elóállítók, akik a lokalitást erősítik és a vonzerôt is növelik. A „Völgy Vidék helyi termékei és fejlesztési lehetőségeik" címmel készült záró tanulmány 54 termelőt sorol fel (BODÓ 2009). Élelmiszer tekintetében a bor mellett több méztermelő, sajtkészítő, zöldség-gyümölcs termeló és palánta elóállító, baromfi és tojástermelő, pálinka készítő, gyümölcs feldolgozó (szörp, lekvár) és cukrász szerepel a listán. A nem élelmiszeripari termékek esetében is sokszínú a kínálat: üvegfestő, kosárfonó, fazekas, grafikus, szobrász, ötvös, szúcs, cipőkészítő, kosárfonó, ékszerkészítő kézmúves, bábkészítő, csuhétermék készítő, gyertyaöntố is van, a rendezvényeken elsősorban az ô termékeiket vásárolhatjuk meg.

A minőségi termékek eloállítását támogatja az egész borvidékre évente meghirdetett Etyek-Budai Borvidéki Borverseny, mely egy hegyközségi borverseny. A borértékelések, borversenyek a szakembereken, kereskedőkön kívül a borszeretóket is vonzzák. A borturizmus hivatás-turizmus jellegú része a borverseny mellett a borvásár, borfesztivál. A térség legnagyobb ilyen jellegú eseménye a Budapest Borfesztivál, mely évente a Budai Várban kerül megrendezésre (2018-ban szeptember 6-9. között), valamint a Budafoki Pezsgó- és Borfesztivál.

Etyek rendelkezik bormúzeummal is, ahol a szőló termesztésével, a bor készítésével és forgalmazásával kapcsolatos eszközök, dokumentumok kerülnek bemutatásra. Ezen kívül híres a Törley Gyúitemény és Látogatóközpont is, ahol a Törley pezsgók történetével ismerkedhetünk meg korabeli relikviák, feljegyzések segítségével.
A bortermelés a helyi kultúra része, nem csak a borászokat, hanem sok lakost is érint, akik civil szervezetekbe tömörültek. A térségben Budafokon 1992-ben alakult meg a Promontorium Borlovagrend és 1993-ban a Szent Benedictus Borrend, melynek alapító tagjai velencei, pázmándi, nadapi, sukorói szőlő́sgazdák közül kerültek ki. Elsődleges feladatuknak tekintik a helyi minőségi bortermelés elősegítését és a hagyományos fajták népszerúsítését.

\subsection{KIEGÉSZÍTŐ VONZERŐK, TÁJÉRTÉKEK}

Természeti és kulturális értékekben igen gazdag vidék. Igaz, az Etyek-Budai borvidékhez tartozó települések nem alkotnak kompakt, zárt egységet, nem ölelik fel a táj teljes egészét. A kimaradt települések számos borászati és egyéb turisztikai vonzeróvel rendelkeznek, és izgalmas partnerei lehetnek a borvidék borturisztikai fejlesztésének.

A legrégebbi védett múemlékek az Árpád-korból származnak: apátsági kereszt Telkiben, a Szent Kereszt templom romja Biatorbágyon, az egykori domonkosrendi templom romja Tökön, az országosan ismert egykori premontrei templom- és kolostor romjai Zsámbékon. Bár a Budafoki Pincerendszer várostörténeti, ipartörténeti jelentósége felülmúlhatatlan, szerencsés, hogy több település is (Páty, Tök) épen maradt pincesorokkal rendelkezik, amelyek turisztikai vonzereje ma még nem jelentős. Az alcsútdobozi golfturizmus és a felcsúti Puskás Labdarúgó Akadémia miatt a sport turizmus csírái is kifejlődtek már. A Töki pompos, mint gasztro-kulturális helyi specialitás, jelentős vonzerő lehetne. A borvidék három körzetének összehasonlítását tartalmazza az 5. táblázat.

Az új borvidéket (1990) és a hozzá tartozó településeket ma még kevéssé ismerik. Boraikat fôleg az ismert márkákhoz kötik (Törley, Nyakas). A borturisztikai forgalom az etyeki fesztiválokra korlátozódik, a velencei térségben pedig az üdülő turizmushoz kapcsolódik. Fő vonzerői:

- A vonzó táj (Pilis, Budai-hegység, Zsámbéki-medence, Etyeki-dombság, Vértesalja, Váli-víz és a Szent László-patak völgye, Duna, Velencei-tó).

- A bor és a hozzá kapcsolódó épített és szellemi értékek (régi pincesorok, fesztiválok, szőlőskertek)

- A vonzó fürdóhely (Velencei-tó környéke).

- Kultúra (fesztiválok, Zsámbéki Színházi Bázis, Budafok, Alcsúti Arborétum).

- Helyi termék (élelmiszer, kézmúves termékek gazdag választéka). 
A borvidék körzeteinek összehasonlítása

\begin{tabular}{|c|c|c|c|}
\hline & Etyeki körzet települlései & Budai körzet települései & Velencei körzet települései \\
\hline települések & $\begin{array}{l}\text { Alcsútdoboz, Biatorbágy, } \\
\text { Etyek, Felcsút, Gyúró, } \\
\text { Kajászó, Martonvásár, } \\
\text { Tordas, Vál, Budapest XXII. } \\
\text { kerület (Budafok) }\end{array}$ & $\begin{array}{l}\text { Budajenö, Budakeszi, } \\
\text { Budapest XII. kerület 9597/1 } \\
\text { hrsz, Páty, Pilisborosjenö, } \\
\text { Telki, Tök, Üröm, Bicske, } \\
\text { Csabdi }\end{array}$ & $\begin{array}{l}\text { Gárdony, Kápolnásnyék, } \\
\text { Nadap, Pákozd, Pázmánd, } \\
\text { Sukoró, Velence }\end{array}$ \\
\hline $\begin{array}{l}\text { oltalom alatt álló dülök } \\
\text { száma a termékleirás } \\
\text { mellékletei alapján }\end{array}$ & 40 & 15 & 9 \\
\hline $\begin{array}{l}\text { szölöterületek } \\
\text { veszélyeztetettsége }\end{array}$ & & $\begin{array}{l}\text { Beépitések veszélyeztetik a } \\
\text { megmaradt szölöterületeket. }\end{array}$ & $\begin{array}{l}\text { Tájhasználati konfliktust } \\
\text { okoz a Velencei-tó környéki } \\
\text { szölöhegyek (történelmi } \\
\text { borvidékek) szinte egybefüggö } \\
\text { beépülése üdülökkel. A } \\
\text { tájesztétikai szempontból } \\
\text { kedvezötlen beépitések } \\
\text { a történelmi borvidékek } \\
\text { (szölöhegyek) területét is } \\
\text { veszélyeztetik. }\end{array}$ \\
\hline $\begin{array}{l}\text { borászat/vendégeket } \\
\text { fogadó, müködö pincék }\end{array}$ & $22 d b$ & $3 d b$ & ( \\
\hline $\begin{array}{l}\text { klasszikus borturizmus } \\
\text { (pincelátogatás, } \\
\text { kóstolás) }\end{array}$ & jellemzö & $\begin{array}{l}\text { felfutóban a Kadarkáink } \\
\text { kertjének köszönhetöen }\end{array}$ & nem jellemzö \\
\hline borút/tanösvény & 3 borút & Kadarkáink kertje & nincs \\
\hline $\begin{array}{l}\text { borút egyesület, } \\
\text { borászati egyesület }\end{array}$ & Etyeki Borút Egyesület & $\begin{array}{l}\text { Budakörnyéki Borkultúra } \\
\text { Egyesület }\end{array}$ & $\begin{array}{l}\text { Velencei-tó környéki Borút } \\
\text { Egyesület }\end{array}$ \\
\hline borlovagrend & Promontorium Borlovagrend & & Szent Benedictus Borrend \\
\hline rendezvények & $\begin{array}{l}\text { Az egész borvidéket átfogó } \\
\text { és megmozgató rendezvények } \\
\text { Etyek és Budafok nevéhez } \\
\text { kötödnek: } \\
\text { Etyeki Pincefesztivál } \\
\text { Etyeki Légyott, Etyeki Piknik, } \\
\text { Etyeki Szüreti Barangoló, } \\
\text { Budafoki pezsgö és } \\
\text { pincefesztivál }\end{array}$ & $\begin{array}{l}\text { János napi borszentelés } \\
\text { (Páty) } \\
\text { Pátyi pincenapok } \\
\text { Pincefalvak napja és } \\
\text { pincefalvak borversenye } \\
\text { (Páty) }\end{array}$ & $\begin{array}{l}5 \text { településen szüreti felvonulás, } \\
\text { bál vagy mulatság }\end{array}$ \\
\hline tájérték & $\begin{array}{l}\text { összesen } 508 \text { db, ebböl } 177 \\
(35 \%) \text { köthetö a szölészethez, } \\
\text { borászathoz }\end{array}$ & $\begin{array}{l}\text { összesen } 697 \text { db, ebböl } 144 \\
(21 \%) \text { köthetö a szölészethez, } \\
\text { borászathoz }\end{array}$ & $\begin{array}{l}\text { összesen } 293 \text { db, ebböl } 14 \\
\text { (5\%) köthetö a szölészethez, } \\
\text { borászathoz }\end{array}$ \\
\hline
\end{tabular}

Forrás: saját szerkesztés

\section{Jövóbeni folyamatok}

A hazai borászatok versenyképességében, a szőlőtermesztés hosszú távú fennmaradásában mind a társadalmi, mind a természeti változásoknak jelentős szerepe lesz. A hazai tudósok a VAHAVA programban kezdtek el foglalkozni a mezőgazdaságban várható változásokkal. Láng István akadémikus a klímaváltozás, a szélsőséges időjárás mezőgazdasági hatásait elemezve rámutatott: az ezzel járó veszteségek a felére csökkenthetők megfelelő talajmúveléssel, a mindenkori csapadékhozam megőrzésével és alkalmazkodóbb fajták kinemesítésével. A klímaváltozás hatására mind a szólőtermesztésre alkalmas területek határai, mind a termesztett szólőfajták, valamint az azokból készített borok karaktere meg fog változni (JÁNOSIMÓZES 2012).

A XXI. században várhatóan bekövetkezó jelentős klímaváltozás alapvetően át fogja rajzolni a 
Lektorált tanulmányok

A klímaváltozás hatásai a szôlőterületekre

\begin{tabular}{|c|c|c|c|}
\hline $\begin{array}{l}\text { A klímaváltozás } \\
\text { általános hatása }\end{array}$ & $\begin{array}{l}\text { A szőlöterületeken } \\
\text { megjelenő hatások }\end{array}$ & $\begin{array}{c}\text { A negatív hatások } \\
\text { mérséklésére tett intézkedések }\end{array}$ & Tájképi hatások \\
\hline klíma melegedése & $\begin{array}{l}\text { szólōtermesztésre való } \\
\text { alkalmasság megváltozása } \\
\text { változó beltartalom }\end{array}$ & új fajták megjelenése & $\begin{array}{l}\text { termesztési mód } \\
\text { megváltozása } \\
\text { következtében a } \\
\text { tájkép is változik }\end{array}$ \\
\hline $\begin{array}{l}\text { hírtelen lezúduló nagyobb } \\
\text { vízmennyiségek }\end{array}$ & $\begin{array}{c}\text { lejtôs területeken a föld } \\
\text { lemosódása } \\
\text { vizhiány kialakulása }\end{array}$ & $\begin{array}{c}\text { lejtőre meróleges sorok } \\
\text { használata } \\
\text { sorközök növényesitése }\end{array}$ & tájkép megváltozása \\
\hline $\begin{array}{c}\text { kártevók és kórokozók } \\
\text { elterjedése }\end{array}$ & $\begin{array}{c}\text { eddig hazánkban jelen nem lévó } \\
\text { kártevók megjelenése }\end{array}$ & $\begin{array}{l}\text { fokozott növényvédelem, } \\
\text { ellenállóbb fajták telepítése }\end{array}$ & $\begin{array}{l}\text { fajtaváltás esetén a } \\
\text { tájkép megváltozása }\end{array}$ \\
\hline
\end{tabular}

Forrás: saját szerkesztés DIVERZITI EGYESÜLET (2012) alapján

világ bortermelését: lesznek olyan területek, ahonnan a szőlőtermesztés kiszorul, és lesznek olyanak is, ahol korábban nem voltak alkalmas területek, de a melegedés hatására megjelenik a szőlőtermesztés. A klímaváltozás hatására a termesztett fajták is meg fognak változni. A területi elterjedés mellett az egyes termőhelyeken jelentós változások várhatók a lejtôre, különösen a meredek lejtóre telepített szőloók esetében is. A hosszú, esô nélküli időszakokban a talaj felső rétege annyira kiszáradhat, hogy a gyorsan lezúduló csapadék nem tud átszivárogni rajta. A lejtők vízelvezető képessége a kevesebb, egyenlőtlenebb eloszlású csapadék miatt vízhiányt okoz ezeken a területeken. A termelőknek fel kell készülniük a területükön addig kevésbé, vagy nem jellemző betegségekre, fertốzésekre, kártevőkre, problémákra. Magyarországon is megjelenhetnek majd az eddig a mediterrán területekre jellemzó kórokozók (DIVERZITI EGYESÜLET 2012) (6. táblázat).

Amennyiben a hazai bortermelés meg kívánja őrizni gazdasági jelentőségét, a szőlótermesztés mellett a borturizmus fejlesztése nyúithat kitörési lehetőséget erre. A borturizmus, a turisztikai hasznosítás egyre nagyobb szerepet kap a borászatok gazdaságos múködésében. A minőségi borok termelése mellett ezért érdemes a gazdaságoknak a táji szempontú fejlesztésekre is egyre nagyobb figyelmet fordítaniuk. Az év szőlóbirtoka verseny keretében kidolgozott értékelési szempontrendszer, ami már most is nagy jelentőséggel bír a borászatok életében, jó példa arra, hogy számos egyéb tényezó mellett a táji szempontokat is figyelembe kell venni a birtokok fejlesztésekor. A versenyben elért jó eredmény komoly marketing értékkel bír a szőlóbirtokok és a látogatók körében. A verseny értékelésének tapasztalatai alapján a 7. táblázatban bemutatott táji szempontok figyelembe vételét javasoljuk a birtokok fejlesztésekor (Csemez Attila, bizottsági tag szóbeli közlése alapján).

A település-, a tájkarakter megórzése érdekében a településeknek 2017 végéig el kellett készíteniük az úgynevezett Települési Arculati Kézikönyveiket, amelyben a borászathoz kapcsolódóan

\section{Szőlőbirtok értékelés táji szempontjai}

\begin{tabular}{|c|c|c|}
\hline $\begin{array}{l}\text { 1. Hagyományokhoz, a tájképhez } \\
\text { illeszkedô ïltetvény }\end{array}$ & $\begin{array}{l}\text { 2. A birtok egésze, a táji adottságok } \\
\text { figyelembe vétele }\end{array}$ & $\begin{array}{l}\text { 3. Elérhetöség, } \\
\text { megközelithetöség }\end{array}$ \\
\hline $\begin{array}{c}\text { az erózió mértéke, } \\
\text { a rézsúk fenntartása, } \\
\text { a fajtaszerkezet, } \\
\text { a sorközök borítottsága, } \\
\text { a felszíni vizek elvezetése, } \\
\text { a soralja gyomossága, } \\
\text { a gyomok irtása, } \\
\text { a támrendszer, } \\
\text { a müvelésmód, } \\
\text { a zöldmunkák. }\end{array}$ & $\begin{array}{c}\text { a honos fafajok alkalmazása, } \\
\text { pince/borház tájba-illeszkedése, } \\
\text { a kert kialakitása, } \\
\text { zöldfelületek megjelenési formája, } \\
\text { a környezet/kert fenntartása, } \\
\text { az anyaghasználat, } \\
\text { a látványkapcsolatok jellege, } \\
\text { a népi motívumok megjelenése, } \\
\text { a pince/borház környezetének rendezettsége. }\end{array}$ & $\begin{array}{c}\text { burkolat jellege, minôsége, } \\
\text { nyomvonalvezetés, } \\
\text { burkolat vízáteresztô képessége, } \\
\text { kísérô növényzet }\end{array}$ \\
\hline
\end{tabular}

Forrás: saját szerkesztés 
elsősorban a pincék, pincesorok kaphattak önálló lehatárolást. A fejlesztésekkor a Települési Arculati Kézikönyv ajánlásait is figyelembe kell venni mind a meglévó, mind a tervezett borászatok, présházak épületeinek és környezetének kialakítása során. Sajnálatosan a szőlőtermesztés területei a legtöbb Arculati Kézikönyvbe csak érintólegesen kerültek be, ezért a termesztési módok megốrzésére a Kézikönyv ajánlásai nem alkalmasak. A település táji adottságaihoz és építészeti kultúrájához alkalmazkodó megjelenés nem csak a településkép szempontjából teszi vonzóvá a létesítményt (présházat, borkínáló helyiséget stb.), hanem turisztikailag is. A települési, táji örökség legfontosabb, kézzel fogható emlékei a tájértékek, ezért a Tájértéktár (www. tajertektar.hu) adatait is érdemes áttekinteni, hogy a gazdálkodási múlt tárgyi/épített és szellemi emlékeivel, hagyományaival megismerkedhessünk az adott területen (MIKHÁZI - SZILVÁCSKU 2010, KOLLÁNYI et al. 2011). Ezért tartottuk fontosnak kiemelni ezeknek az értékeknek a meglétét és számát az Etyek-Budai borvidéken. A tájértékekre alapozott, a település múltját bemutató fejlesztések megadhatják azt az egyediséget, amit a turisták manapság utazásaik, szabadidős tevékenységeik során keresnek. A mennyiségi termelésről a minőségi termelésre váltás a bortermelés során új turisztikai szegmenset nyitott meg a hazai borászatok számára is, melyek csak akkor lehetnek hosszútávon sikeresek, ha figyelembe veszik a környezeti és társadalmi változásokat, és a fejlesztéseiket a táji adottságokkal harmóniában valósítják meg.

\section{5. Összefoglalás}

Az egyediség kialakításában, a turisztikai márka felépítésében nagy szerepe van az adottságok minél szélesebb körú feltárásának. A magyar borvidékek a bemutatott felmérések alapján itthon sem kellóen ismertek. A fogyasztók nem tudják azonosítani az egyes borvidékekhez tartozó szőló- és borfajtákat. Azt is megfigyelhetjük, hogy a borkóstolás, pincelátogatás ritkán elsôdleges célja az utazásnak. Legtöbbször csak kiegészítô program az üdülés során. A kis borvidékeknek - mint az Etyek-Budai borvidék - különösen nagy erőfeszítésükbe kerül elérni és megnyerni a potenciális látogatókat.

A mintaként választott borvidék története hullámzó. A tájtörténeti kutatásunk során feltártuk, hogy nagy felemelkedések és hanyatlások váltották egymást, mely változásoknak társadalmi, gazdasági és környezeti okai is voltak. A jelenlegi virágzás alapja, hogy felismerték a történelemi múltban és a hagyományokban rejló értékeket, és a fejlesztéseket azokra alapozták. Így kialakult az a sajátos kínálat, arculat és programrendszer, mely mára márkává vált és egy stabil, visszajáró vendégkört biztosít.

\section{Felhasznált irodalom}

BÁRCZINÉ K. J. - SALLAY Á. - CSEMEZ A. (2011): Landscape design tasks based on the Budavidék Greenway. Acta Universitatis Sapientiae. Agriculture and Environment Supplement. 3. pp. 68-79.

BODÓ E. T. (2009): Völgy Vidék Gazdaságfejlesztési Stratégiája. Völgy Vidék helyi termékei és fejlesztési lehetốségeik. Zárótanulmány. http://www.volgyvidek.hu/attachments/VVK_helyi_termek_tanulmany.pdf, Letöltve: 2017. november 1.

BORMARKETING MÜHELY NONPROFIT KFT. (2013a): Bormarketing munkát támogató piackutatás a magyar borpiacon. Országos fogyasztói borkutatás. Tanulmány. p. 50.

BORMARKETING MÚHELY NONPROFIT KFT. (2013b): A magyar lakosság borfogyasztási szokásai. Turizmus Bulletin. 15(1). pp. 50-56.

CSEMEZ A. - MŐCSÉNYI M. (1983): Egyedi tájértékek: Az általános tájuédelem alapjául szolgáló tájértékelési módszer kidolgozása. Kertészeti Egyetem, Tájrendezési Tanszék. Kézirat.

DIVERZITI EGYESÜLET (2012): A hazai bortermelés a klímaváltozás tükrében. http://www.diverziti.hu/4549/a-hazai-bortermeles-a-klimavaltozas-tukreben/, Letöltve: 2017. november 1.

EEA (European Environment Agency) (2012): A European Environment Agency 2000-tôl 2012-ig tartó Corine Land Cover adatbázisának területi adatai. http://www.eea.europa.eu, Letöltve: 2017. november 1 .

FÉNYES E. (1851): Magyarország geográfiai szótára, mellyben minden város, falu és puszta, betûrendben körülményesen leíratik. Kozma Vazul nyomdája, Pest.

HNT (HEGYKÖZSÉGEK NEMZETI TANÁCSA) (2017): http://hnt.hu/statisztikak/termoterulet-es-termesmennyiseg/, Letöltve: 2018. március 21.

JÁNOSI-MÓZES T. (2012): A klímaváltozás hatása a hazai bortermelésre: egy iparág jövóje forog kockán. https://sciart.eu/hu/2012-03-09-1203/1/klimavaltozas-hatasa-hazai-bortermelesre-egy-iparag-jovoje-forog-kockan, Letöltve: 2017. november 1.

KARÁCSON I. (ford.) (1904): Evlia Cselebi török világutazó magyarországi utazásai 1660-1664. MTA, Budapest.

KELETI K. (szerk.) (1875): Magyarország szőlôszeti statistikája 1860-1873. Nemzetközi Statisztika 1. rész. Országos Magyar Királyi Statisztikai Hivatal, Budapest. 
Lektorált tanulmányok

KOLLÁNYI L. - CSEMEZ A. - SZILVÁCSKU ZS. - SALLAY Á. - FILEPNÉ K. K. -MOLNÁR J. L. - MIKHÁZI ZS. (2011): Téka Projekt (TájÉrték KAtaszter): Norvég finanszírozási Alapból támogatott nemzetközi projekt. Kutatási jelentés.

KSH (KÖZPONTI STATISZTIKAI HIVATAL) (1988): Szőlooültetvények összeírása. Földterület: községsoros adatok, 1895-1984.

MAGYAR TURIZMUS RT. - M.Á.S.T. PIAC- ÉS KÖZVÉLEMÉNYKUTATÓ TÁRSASÁG (2006): A magyar lakosság étkezési és alkoholfogyasztási szokásai és Magyarország gasztronómiai imázsa 2005-ben. Turizmus Bulletin. 10(1). pp. 39-49.

MAGYAR TURIZMUS ZRT. (2006): A magyar lakosság borfogyasztási szokásai. Turizmus Bulletin. 10(3). pp. 68-69.

MAGYAR TURIZMUS ZRT. (2013): A bor és gasztronómia, mint turisztikai termék. Turizmus Bulletin. 15(1). pp. 45-49.

MICHALKÓ G. - BOROS SZ. - CSAPÓ J. - HAPP É. - HORVÁTH P. - HUSZ A. - JÓNÁS-BERKI M. - LÓRINC K. - MÁTÉ A. - PRINTZ-MARKÓ E. - PRISZINGER K. - RÁTZ T. - REMENYIK B. -SZABÓ G. - KALMÁRNÉ RIMÓCZI CS. (2011): Turisztikai terméktervezés és fejlesztés. Pécsi Tudományegyetem, Pécs.

MIKHÁZI ZS. - SZILVÁCSKU ZS. (2010): Országos tájérték adatbázis - A magyarországi vonzerók gyújteménye. Turizmus Bulletin 14(3). pp. 12-16.

MSZ 20381:2009: Természetvédelem. Egyedi tájértékek kataszterezése.
NAGY BOR TESZT (2016): http://vinoport.hu/aktualis/igy-keszult-az-orszag-legnagyobb-boros-felmerese/3157, Letöltve: 2017. november 1.

SALLAY Á. - JOMBACH S. - FILEPNÉ KOVÁCS K. (2012): Landscape changes and function lost landscape values. Applied Ecology and Envinronmental Research. 10(2). pp. 157-172.

SALLAY Á. - MÁTÉ K. - MIKHÁZI ZS. - CSEMEZ A. (2017): Az Etyek-Budai borvidék tájváltozásai. In: Blanka V. - Ladányi Zs. (szerk.): Interdiszciplináris tájkutatás a XXI. században. VII. Magyar Tájökológiai Konferencia. Szegedi Tudományegyetem, Földrajzi és Földtudományi Intézet, Szeged. Tanulmánykötet. pp. 512-519.

SALLAY Á. - MIKHÁZI ZS. - FILEPNÉ K. K. CSEMEZ A. - EGYED A. (2010): Turisztikai desztinációk táji adottságainak optimális használata. In: Andrássy A. (szerk.): „Gazdaság és társadalom" Nemzetközi Tudományos Konferencia. Nyugat-magyarországi Egyetem, Közgazdaságtudományi Kar, Sopron. Tanulmánykötet. CD-kiadvány.

VÁRHELYI T. (2012): Borturizmus. Líceum Kiadó, Eger.

\section{Internetes források}

Budafoki Pezsgó és Bor Fesztivál: www.budafokiborfesztival.hu Etyeki Piknik: http://etyekipiknik.hu Tájértéktár: www.tajertektar.hu 